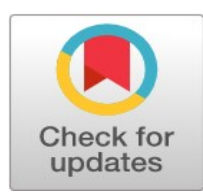

\title{
Factors affecting intention to repurchase for e-commerce in Thailand
}

\author{
Theeraphat Polcharoensuk ${ }^{1^{*}}$, Khanchitpol Yousapornpaiboon ${ }^{2}$ \\ ${ }^{1,2}$ College of Graduate Study in Management, Khon Kaen University, Thailand
}

\author{
Keywords \\ E-commerce intention \\ Technology acceptance model \\ Trust \\ Satisfaction \\ Perceived of usefulness
}

Received: 18 June 2017

Accepted: 26 July 2017

Published: 21 August 2017

\begin{abstract}
This study aims to study the factors that affect an individual's intention to repurchase from ecommerce system in Thailand by integrating two models-Technology Acceptance Model (TAM) and an Expectation Confirmation Model (ECM) into one research model. Four hundred online questionnaires were collected from Thais who have had at least two experiences of purchasing goods or services through an e-commerce system in Thailand. The results indicate that (1) perceived ease of use has a direct impact on trust and perceived usefulness, (2) confirmation has a direct impact on perceived usefulness and satisfaction, (3) trust has a direct impact on perceived usefulness and online repurchase intention, (4) perceived usefulness has a direct impact on satisfaction and online repurchase intention, (5) satisfaction has a direct impact on online repurchase intention. It is evident that satisfaction is the most influential factor affecting an online repurchase intention while confirmation is the strongest factor affecting satisfaction. The evidence from this study suggests that satisfaction $\left(R^{2}=0.761\right)$ is the main factor that generates intention to repurchase form an e-commerce system, hence entrepreneurs should take satisfaction as one of their highest considerations.
\end{abstract}

(C) 2017 The Author(s). Published by TAF Publishing.

\section{INTRODUCTION}

In the modern day, trends of buying goods and services through the internet play an important role in the lives of consumers. This is due to the continuous development of technology and communication devices which changed consumer behaviour in way of communicating, purchasing goods and services. As Technology has become part of daily life and one of the media that have been in market since 1970's and continue to change the consumer purchase goods or services.

In the past, there were factors that could explain the adoption and intentions of using information systems such as the TAM (Davis, 1989) was developed from Theory of Reasoned Action (TRA), which explains the understanding and prediction of human behaviour (Ajzen \& Fishbein, 1980). According to the survey results from Electronic
Transactions Development Agency (ETDA) which is set up under Ministry of Information and Communication Technology (MICT) to conduct studies and research while providing support for the Electronic Transactions Commission, the results show the value of e-commerce between 2015 and 2016 growing from $2.2 \mathrm{mb}$ to $2.5 \mathrm{mb}$ or $12.42 \%$ (Electronic Transactions Development Agency, 2016).

Entrepreneurs are also increasing to be 527,324 accounts in 2016. At the same time, the Thai government has announced a new economic model that aims to change the current economic structure from heavy industries for continued economic growth (Thailand 3.0) to an economy driven by technology and innovation called. Thailand 4.0 (Maesincee, 2016) which makes many entrepreneurs recognize the importance of using online channels as a gateway to trade their goods and services. E-commerce provides ac-

\footnotetext{
* Corresponding author: Theeraphat Polcharoensuk1

†Email: T.Polcharoensuk@gmail.com
} 
cess to a large number of consumers at very low cost. These benefits allow entrepreneurs to enter the online market easily.

The first things that entrepreneurs need to consider are creating awareness by letting consumers know the store's e-commerce website, ease of use i.e., sorting goods/services, and option for payment. Entrepreneurs should pay more attention to the reliability of the system since there is no storefront to purchase goods and services. According to Yang et al. (2009), the credibility and transparency of e-commerce websites are important for entrepreneurs.

Therefore, a website should state the privacy policy and accurately describe the goods and services. The websites that do not pay attention to reliability will negatively affect the intention to re-purchase and also cause negative word of mouth (Goles et al., 2009). During the purchase of goods and services through the system, consumers will have an expectation of services and compare with brick and mortar shopping experiences. Expectations often arise from the experience of others concerning the goods or services through review or word of mouth. Bhattacherjee (2001a) states that expectation of confirmation is the antecedent variables before customer satisfaction, and if one's expectation from the purchase of goods and services is higher than the actual experience gained. It will cause positive customers intent to repurchase. This intention comes from the consumer's inner sense of satisfaction.

In order to make a business run smoothly, seamlessly, and sustainably, entrepreneurs need to consider the factors that can retain the consumer and drive consumer intention to repurchase through the e-commerce system. In order to make the digital economy for "Thailand 4.0", we will need to encourage consumers and entrepreneurs to understand e-commerce.

Factors affecting intention to repurchase for ecommerce in Thailand are the topics e-commerce entrepreneurs need to understand to encourage consumers to re-purchase their goods or services. The researcher has adopted a concept of TAM to describe and predict consumer behaviour in the information technology field and the model confirms the expectation of continuous use of information systems (ECM) which developed from ECT and predicts the continued use of information systems.

\section{LITERATURE REVIEW}

The study of the factors affecting intention to repurchase for E-commerce in Thailand focuses on the factors from integrated model for customer online repurchase intention. Concepts, theory, and relevant research were studied as follows: TAM, proposed by (Davis, 1989; Venkatesh \& Davis, 2000 ) is one of the most influential theories to understand user acceptance of technology. TAM is an extension of the TRA which explains the understanding and predicting of human behaviour. (Ajzen \& Fishbein, 1980). The TAM describes the factors that affect the adoption of technology by users. This well-accepted model has been used in Information system and management research before (Martins \& Kellermanns, 2004).

Accordingly, perceived ease of use and perceived usefulness are two main factors of adoption of the new technology. The ECT developed by (Oliver, 1980) is widely studied in consumer behaviour, consumer satisfaction, and post purchase consumer behaviour. When customers have a high level of satisfaction, the repurchase rate will also increase (Anderson \& Sullivan, 1993). The predictive ability of this theory has been applied to the repurchase study of a variety of goods and services. Bhattacherjee (2001b) proposed the theoretical model that was adapted from ECT which is used for assessing and measuring consumer satisfaction of products or services and post-purchase behaviour.

Bhattacherjee (2001b) adapted ECT and created a new model for IT continuance which studies expectation effects on technology. From the study found that confirmation directly affects perceived usefulness. Bhattacherjee (2001b) has not included an expectation factor since expectation is a factor for pre-purchase. ECM is focusing on post-purchase behaviour. Retention is an important terms in marketing (Fullerton, 2005; Morgan \& Hunt, 1994) which has the same meaning as repurchase, and can be defined as a consumer's behaviour who is willing to purchase the same goods or services for more than one time. Repurchase and the factors influencing it have been tested in several academic studies (Seiders et al., 2005; Wanke \& Fiese 2004; Wen et al., 2011).

\section{Conceptual Framework}

Conceptual framework of this research is shown in Figure 1. 


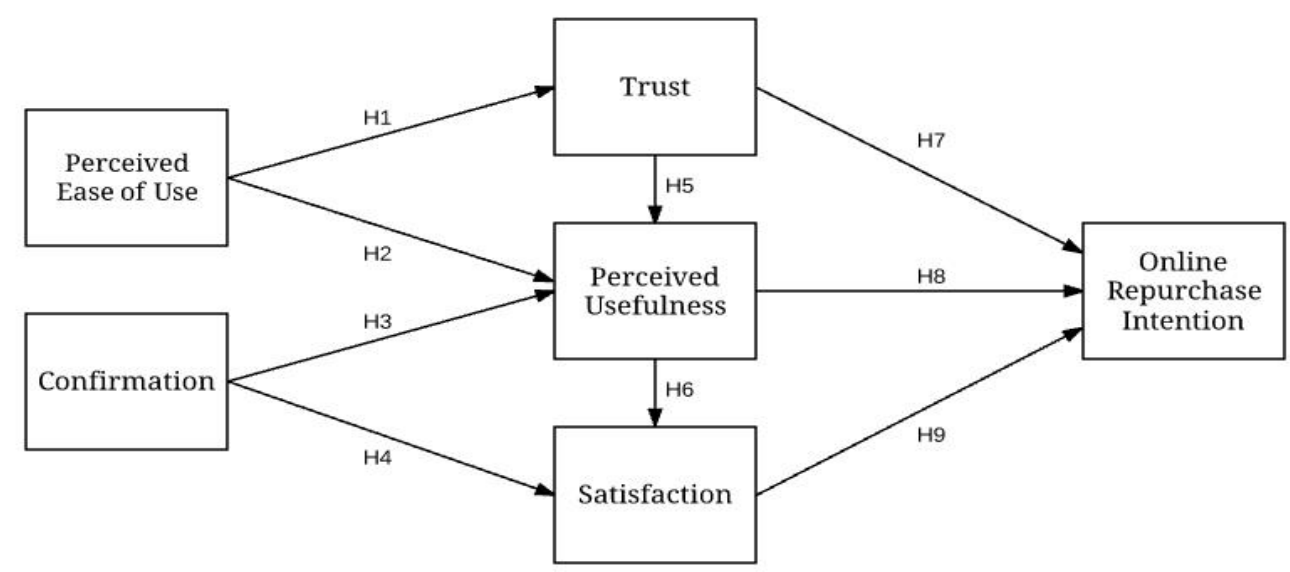

FIGURE 1. Conceptual framework

\section{Hypotheses}

The objective of this study is to review the factors of online repurchase intention. Wen et al. (2011) have developed an integrated model for customer online repurchase intention including factors: perceived ease of use, perceived usefulness, confirmation, and satisfaction. Therefore, the hypotheses of this study were as follows:

H1: perceived ease of use has a positive impact on a customer's trust.

H2: perceived ease of use has a positive impact on a customer's perceived usefulness.

H3: confirmation has a positive impact on a customer's perceived usefulness.

H4: confirmation has a positive impact on a customer's satisfaction.

H5: trust has a positive impact on a customer's perceived usefulness.

H6: perceived usefulness has a positive impact on a customer's satisfaction.

H7: trust has a positive impact on a customer's online repurchase intention.

H8: perceived usefulness has a positive impact on a customer's online repurchase intention.

H9: satisfaction has a positive impact on a customer's online repurchase intention.

\section{METHODOLOGY}

\section{Sample}

An Internet-based questionnaire was developed to collect data. The questionnaire was divided into three sections. The first section of the survey was designed to get personal information from participants who have had at least two experience of purchasing goods or services through e- commerce system. The second section of this survey was designed to get information on behaviour in purchasing goods and services. The respondents were asked to answer the reason for purchasing, the frequency of purchasing, time and money spent, and frequency of visiting the e-commerce website. The third section of this survey contained twenty-three questions that measured the six factors in the model. A nine-point-Likert scale has been used to measure. These questions were selected from related research and modified for Thai respondents.

\section{Data Collection}

Two research advisers examined all of the questions to verify the items are appropriate, easy to understand, and work with present study. The questionnaires with revised questions were subsequently distributed through an internet online survey. The data collection took place in March of 2017 and collected large sample of four hundred Thais who have had at least two experiences of purchasing goods or services through an e-commerce website.

\section{Sampling Method Choice}

This study used Non-Probability Sampling, which selects a sample that cannot measure probability of each population units. Convenience sampling methods were applied by providing an online questionnaire to the respondents.

\section{Measurement Tools}

After collecting four hundred internet-based questionnaires $(N=400)$, reliability tests were given for multi-item instruments. Cronbach's Alpha was used to assess testretest reliability. The reliability of constructs was examined 
using Cronbach's Alpha with a separate sample $(N=30)$. Cronbach's Alpha value of 0.7 or higher suggests good reli- ability (Churchill Jr, 1979). The latent reliability was shown to be acceptable as indicated in Table 1.

TABLE 1. Sources of questionnaire items

\begin{tabular}{lcc}
\hline \hline Factors Affecting Intention to Repurchase for E-Commerce in Thailand & No. of Questions & Reliability: Cronbach's alpha (n= 30) \\
\hline Perceived Usefulness (U) & 5 & 0.845 \\
Perceived ease of use (E) & 3 & 0.851 \\
Trust (T) & 5 & 0.846 \\
Confirmation (CONF) & 3 & 0.854 \\
Satisfaction (SAT) & 4 & 0.936 \\
Online Repurchase Intention (ONRI) & 3 & 0.876 \\
\hline
\end{tabular}

\section{FINDINGS}

\section{Demographics of the Respondents}

From 400 responses, more than half of respondent were fe- male (56\%) and over half were in 25- 35 age group (56\%). Respondents chose to use e-commerce because it's convenient

TABLE 2 . Participants demographics

\begin{tabular}{|c|c|c|}
\hline Item & Characters & Percentage \\
\hline \multirow[t]{2}{*}{ 1. Gender } & Male & 44.0 \\
\hline & Female & 56.0 \\
\hline \multirow[t]{5}{*}{ 2. Age } & Below 25 & 7.0 \\
\hline & $25-35$ & 56.0 \\
\hline & $36-45$ & 24.0 \\
\hline & $46-55$ & 3.5 \\
\hline & above 55 & 9.5 \\
\hline \multirow[t]{4}{*}{ 3. Reasons for using e-commerce } & Convenient & 46.3 \\
\hline & Goods/Services are not available from store & 19.8 \\
\hline & Price cheaper & 16.0 \\
\hline & Time-saving & 18 \\
\hline \multirow{4}{*}{ 4. Frequency for using e-commerce At least 1 time a month } & 61.0 & \\
\hline & $2-3$ time per month & 17.0 \\
\hline & $3-4$ time per month & 15.0 \\
\hline & More than 5 times & 7.0 \\
\hline \multirow[t]{4}{*}{ 5. Time spent on e-commerce per week } & $0-15$ Minutes & 4.5 \\
\hline & $16-60$ Minutes & 49.8 \\
\hline & $1-3$ hours & 26.8 \\
\hline & More than 3 hours & 19.0 \\
\hline \multirow[t]{4}{*}{ 6. Money spent on e-commerce within one year } & Less than 5000 Baht & 62.5 \\
\hline & $5001-25000 \mathrm{Baht}$ & 21.5 \\
\hline & $25001-50000$ Baht & 11.0 \\
\hline & More than 50000 Baht & 5.0 \\
\hline \multirow[t]{5}{*}{ 7. E-commerce website that frequent shopping on } & 11 street & 8.3 \\
\hline & Central Online & 11.8 \\
\hline & Lazada Thailand & 66.8 \\
\hline & WeLoveShopping & 9.5 \\
\hline & Other & 3.8 \\
\hline
\end{tabular}


TABLE 3 . Sources of questionnaire items

\begin{tabular}{|c|c|c|c|c|c|c|}
\hline Variables & Perceived Usefulness (U) & Perceived ease of Use (E) & Perceived ease of Use (E) & $\begin{array}{c}\text { Satisfaction (SAT) } \\
\end{array}$ & Trust (T) & 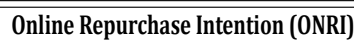 \\
\hline Perceived Usefulness (U) & 1 & & & & & \\
\hline Confirmation (CONF) & $0.534^{* *}$ & $0674^{* *}$ & 1 & & & \\
\hline Trust (T) & $0.566^{* *}$ & $0.675^{* *}$ & $0.728^{* *}$ & $0.680^{* *}$ & 1 & \\
\hline Online Repurchase Intention (ONRI) & $0.643^{* *}$ & $0.709^{* *}$ & $0.778^{* *}$ & $0.863^{* *}$ & $0.670^{* *}$ & 1 \\
\hline
\end{tabular}

** Statistically significant at the 0.01 level

(46.3\%), were willing to buy one good/service per month $(61 \%)$ but spent at least $16-60$ mins per week (49.8\%), spent less than 5,000 baht for shopping (62.5\%), and chose to shop at Lazada Thailand (66.8\%). This paper used SPSS to analyse the demographic data as shows in Table 2. A study of the relationship of variables by Pearson's correlation whether factors variables were correlated to obtain the data is shown in Table 3. Table 3, shows that rela- tionship between perceived ease of use, perceived usefulness, confirmation, satisfaction, and trust was found to be correlated with online repurchase intention. The ranks of correlation coefficients were as follows: Rank 1: satisfaction $(r=0.863)$, rank 2: confirmation $(r=0.778)$, rank 3 : perceived usefulness $(r=0.709)$,

rank 4: trust $(r=0.670)$, and perceived ease of use $(r=$ $0.643)$.

TABLE 4 . Multiple regression analysis of perceived ease of use influences trust

\begin{tabular}{lccccc}
\hline \hline Model & Unstandardized Coefficients & \multicolumn{2}{c}{ Standardized Coefficients } & \\
& $\beta$ & Std. Error & $\beta$ & $\boldsymbol{t}$ & Sig. \\
\hline (Constant) & 1.912 & 0.314 & & 6.095 & 0.000 \\
Perceived ease of use $(U)$ & 0.594 & 0.043 & 0.566 & 13.705 & $0.000^{* *}$ \\
\hline \hline$R=0.566, R 62=0.321$, Std. Error of the estimate $=1.07929^{* *} p<0.05$ & & &
\end{tabular}

From Table 4, the results of the hypothesis testing by linear regression analysis in multiple regression model found that factors affecting trust can describe the variance of per- ceived ease of use by $32.1 \%\left(R^{2}=0.321\right)$. The remaining was due to other variables that were not taken into account.

TABLE 5. Multiple regression analysis of perceived ease of use, trust and confirmation influences perceived usefulness

\begin{tabular}{lccccc}
\hline \hline Model & Unstandardized Coefficients & \multicolumn{3}{c}{ Standardized Coefficients } & \\
& $\beta$ & Std. Error & $\beta$ & $\boldsymbol{t}$ & Sig. \\
\hline (Constant) & 0.848 & 0.272 & & 3.112 & 0.002 \\
Perceived ease of use (U) & 0.280 & 0.043 & 0.267 & 6.536 & $0.000^{* *}$ \\
Trust (T) & 0.291 & 0.050 & 0.291 & 5.782 & $0.000^{* *}$ \\
Confirmation (CONF) & 0.329 & 0.051 & 0.319 & 6.504 & $0.000^{* *}$ \\
\hline \hline
\end{tabular}

$\overline{R=0.756, R 62=0.572 \text {, Std. Error of the estimate }=0.85937^{* *} p<0.05}$

From Table 5, the results of the hypothesis testing by linear regression analysis in multiple regression model found that factors affecting perceived usefulness can describe the variance perceived ease of use, trust, and confirmation by $57.2 \%(R 62=0.572)$. The remaining was due to other variables that were not taken into account.

TABLE 6. Multiple regression analysis of perceived usefulness and confirmation influences satisfaction

\begin{tabular}{lccccc}
\hline \hline Model & Unstandardized Coefficients & \multicolumn{3}{c}{ Standardized Coefficients } & \multicolumn{1}{c}{ Sig. } \\
& $\beta$ & Std. Error & $\beta$ & & $\boldsymbol{t}$ \\
\hline (Constant) & 0.351 & 0.190 & & 1.846 & 0.066 \\
Perceived Usefulness (U) & 0.368 & 0.034 & 0.371 & 10.770 & $0.000^{* *}$ \\
Confirmation (CONF) & 0.578 & 0.035 & 0.566 & 16.423 & $0.000^{* *}$ \\
\hline \hline
\end{tabular}

$R=0.861, R^{2}=0.742$, Std. Error of the estimate $=0.66056^{* *} p<0.05$ 
From Table 6, the results of the hypothesis testing by linear regression analysis in multiple regression model found that factors affecting satisfaction can describe the vari- ance perceived usefulness and confirmation by $74.2 \%\left(R^{2}=\right.$ 0.742 ). The remaining was due to other variables that were not taken into account.

TABLE 7. Multiple regression analysis of perceived usefulness, trust, and satisfaction influences online intention to repurchase

\begin{tabular}{lccccc}
\hline \hline Model & Unstandardized Coefficients & \multicolumn{2}{c}{ Standardized Coefficients } & \\
& $\beta$ & Std. Error & $\beta$ & $\boldsymbol{t}$ & Sig. \\
\hline (Constant) & 0.0520 & 0.193 & & 2.692 & 0.007 \\
Perceived Usefulness (U) & 0.093 & 0.042 & 0.088 & 2.228 & 0.026 \\
Trust (T) & 0.136 & 0.038 & 0.129 & 0.3614 & $0.000^{* *}$ \\
Satisfaction (SAT) & 0.754 & 0.042 & 0.709 & 17.750 & $0.000^{* *}$ \\
\hline \hline
\end{tabular}

$\overline{R=0.872, R^{2}=0.761, \text { Std. Error of the estimate }=0.67761^{* *} p<0.05}$

From Table 7, the results of the hypothesis testing by linear regression analysis in multiple regression model found that factors affecting online intention to repurchase can de- scribe the variance perceived usefulness, trust, and satisfac tion by $76.1 \%\left(R^{2}=0.761\right)$. The remaining was due to other variables that were not taken into account.

TABLE 8. Summary of hypotheses tests

\begin{tabular}{lc}
\hline \hline Hypotheses & Result \\
\hline H1: perceived ease of use has a positive impact on a customer's trust. & Yes \\
H2: perceived ease of use has a positive impact on a customer's perceived usefulness. & Yes \\
H3: confirmation has a positive impact on a customer's perceived usefulness. & Yes \\
H4: confirmation has a positive impact on a customer's satisfaction. & Yes \\
H5: trust has a positive impact on a customer's perceived usefulness. & Yes \\
H6: perceived usefulness has a positive impact on a customer's satisfaction. & Yes \\
H7: trust has a positive impact on a customer's online repurchase intention. & Yes \\
H8: perceived usefulness has a positive impact on a customer's online repurchase intention. & Yes \\
H9: satisfaction has a positive impact on a customer's online repurchase intention. & Yes \\
\hline \hline
\end{tabular}

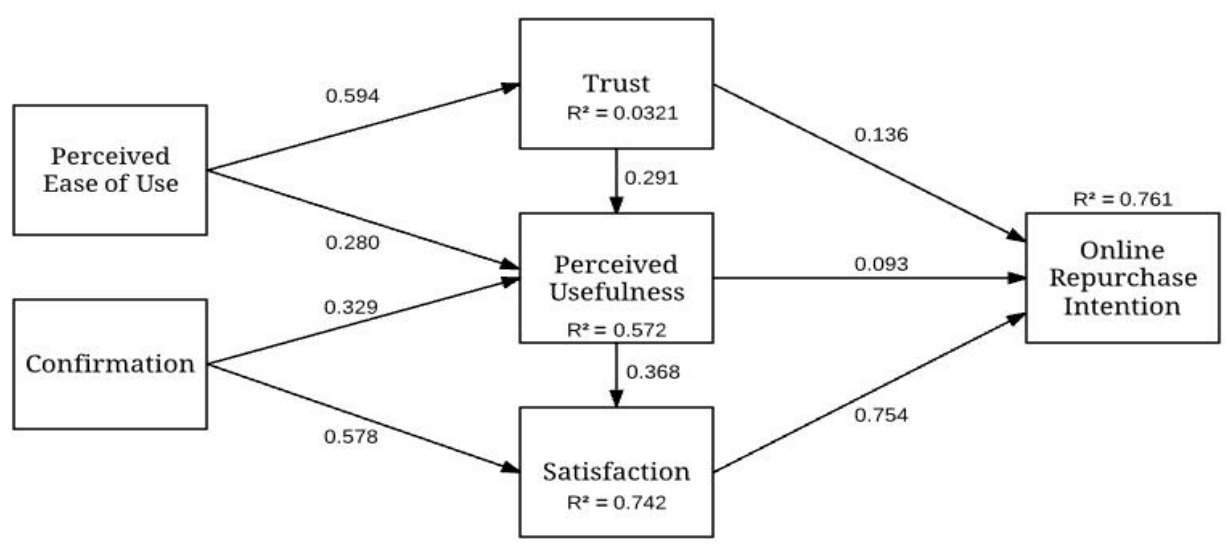

FIGURE 2 . Structural path coefficients 


\section{Summary of Hypothesis Testing Results}

Based on the analysis of inferential statistics to test assumptions the results of the hypothesis test can be summarized in Table 8.

\section{DISCUSSION}

In this study, integrated model for customer online repurchase intention (Wen et al., 2011) has been reviewed and applied for factors affecting intention to repurchase form e-commerce in Thailand. TAM by Davis (1989), and expectation of continuous use of information systems (Bhattacherjee, 2001b) are based on the conceptual framework. Based on this finding, the results show that trust has a positive effect on online repurchase intention being statistically significant at the 0.05 level, in line with study by Gefen et al., (2003). The purpose of this research was to investigate experienced repeat online shoppers on the trust and TAM for online shopping. Perceived usefulness has a positive effect on online repurchase intention, in line with a study from Wen et al., (2011); Bhattacherjee, (2001b). satisfaction has a positive effect on online repurchase intention, in line with the study (Innis, 1991; Oliver, 1980; Oliver \& Bearden, 1985; Stauss \& Neuhaus, 1997). In marketing perspective, satisfaction is considered the main factor for customer retention for online and offline businesses. (Keiningham et al., 2007; Gupta \& Zeithaml, 2006; Morgan \& Rego, 2006).

\section{CONCLUSION}

This study examines the variables from an integrated model for customer online repurchase intention. Satisfaction was the most significant for online repurchase intention, followed by trust and perceived usefulness. The relationship between the six factors can be considered to improve the sustainability of the e-commerce business:

- Perceived ease of use is the factor that helps entrepreneurs understand the needs of improvement for an e-commerce website and keep e-commerce procedures uncomplicated. - Perceived usefulness is the factor that entrepreneurs need to be considered for strategies to make the customer realize the benefits of using e-commerce; save time, convenient, provide a variety of goods/services which will lead to shopping efficiently. From the study, perceived usefulness can lead to customer satisfaction and the intention to repurchase from an e-commerce website.

- Trust plays the important role for credibility of ecommerce which customer perceived from the confident level on e-commerce that can be trusted to provide personal information.

- Confirmation is leaned over for satisfaction. Entrepreneurs need to be considering a study on user experience of purchasing goods and services. This will result in perceived usefulness and customer satisfaction to be more satisfied.

- Customer Satisfaction, based on the findings, is the most important factor affecting intention to repurchase which means. Thais are considered to repurchase goods/service once they're satisfied. Entrepreneurs should take satisfaction as one of their highest considerations for improving e-commerce website.

\section{LIMITATIONS AND FUTURE STUDIES} Limitations

This study focuses on a customer online repurchase intention which did not consider other important aspects of consumer behaviour such as customer loyalty, online shopping experiences, and cost switching. Due to limited time, it was not possible to explore on demographic which may show in-depth detail for marketing purposes.

\section{Future Studies}

Based on the study of a model technology acceptance and an expectation confirmation model for IS, it makes us aware of the intention to repurchase from e-commerce in Thailand and also allows other researchers to conduct research on topics related of this can be used as a basis for further research. Future studies could extend the framework by integrating with consumer experience on e-services as developed areas of research.

\section{REFERENCES}

Ajzen, I., \& Fishbein, M. 1980. Understanding attitudes and predicting social behavior. Englewood Cliffs, NJ: Prentice- Hall. Anderson, E.W., \& Sullivan, M.W. 1993. The antecedents and consequences of customer satisfaction for firms. Marketing Science, 12(2): 125-143. DOI: 10.1287/mksc.12.2.125

Bhattacherjee, A. 2001a. An empirical analysis of the antecedents of electronic commerce service continuance. Decision Support Systems, 32(2): 201-214. DOI: 10.1016/S0167-9236(01)00111-7 
25(3): 351-370. DOI: $10.2307 / 3250921$

Churchill Jr, G.A. 1979. A paradigm for developing better measures of marketing constructs. Journal of Marketing Re- search, 16(1): 64-73. DOI: $10.2307 / 3150876$

Davis, F. D. 1989. Perceived usefulness, perceived ease of use, and user acceptance of information technology. MIS Quar- terly, 13(3): 319-340. DOI: $10.2307 / 249008$

Electronic Transactions Development Agency. 2016. Value of E-Commerce Survey in Thailand 2016 Bangkok.

URL: goo.gl/618aUm. Last accessed on 3 April, 2017.

Fullerton, G. 2005. The impact of brand commitment on loyalty to retail service brands. Canadian Journal of Adminis- $\quad$ trative Sciences, 22(2): 97-110. DOI: 10.1111/j.1936-4490.2005.tb00712.x

Goles, T., Rao, S.V., Lee, S., \& Warren, J. 2009. Trust violation in electronic commerce: Customer concerns and reactions. Journal of Computer Information Systems, 49(4): 1-9.

Gupta, S., \& Zeithaml, V. 2006. Customer metrics and their impact on financial performance. Marketing Science, 25(6): 718-739. DOI: $10.1287 / \mathrm{mksc} .1060 .0221$

Innis, D.E. 1991. Customer service, repurchase intentions, market orientation and firm performance in the channel. Unpublished doctoral dissertation, Ohio State University, Ohio, $\mathrm{OH}$.

Keiningham, T.L., Cooil, B., Aksoy, L., Andreassen, T.W., \& Weiner, J. 2007. The value of different customer satisfaction and loyalty metrics in predicting customer retention, recommendation, and share-of-wallet. Managing Service Quality: An International Journal, 17(4): 361-384. D0I: 10.1108/09604520710760526

Maesincee, S. 2016. Strengthening from within Linking Thai economy to the world. URL: goo.gl/z1W8id. Last accessed on 3 March, 2017.

Martins, L.L., \& Kellermanns, F.W. 2004. A model of business school students' acceptance of a web-based course manage- ment system. Academy of Management Learning \& Education, 3(1): 7-26. DOI: 10.5465/AMLE.2004.12436815

Perea Monsuwé, T.Y., Dellaert, B.G., \& De Ruyter, K. 2004. What drives consumers to shop online? A literature review. Inter- national Journal of Service Industry Management, 15(1): 102-121. D0I: 10.1108/09564230410523358

Morgan, N.A., \& Rego, L.L. 2006. The value of different customer satisfaction and loyalty metrics in predicting business per- formance. Marketing Science, 25(5): 426-439. DOI: 10.1287/mksc.1050.0180

Morgan, R.M., \& Hunt, S.D. 1994. The commitment-trust theory of relationship marketing. The Journal of Marketing, 2(4):

20-38. DOI: $10.2307 / 1252308$

Oliver, R.L. 1980. A cognitive model of the antecedents and consequences of satisfaction decisions. Journal of Marketing

Research, 5(2): 460-469. DOI: 10.2307/3150499

Oliver, R.L., \& Bearden, W.O. 1985. Disconfirmation processes and consumer evaluations in product usage. Journal of Busi- $\quad$ ness Research, 13(3): 235-246. DOI: 10.1016/0148-2963(85)90029-3

Seiders, K., Voss, G.B., Grewal, D., \& Godfrey, A.L. 2005. Do satisfied customers buy more? Examining moderating influences in a retailing context. Journal of Marketing, 69(4): 26-43. DOI: 10.1509/jmkg.2005.69.4.26

Stauss, B., \& Neuhaus, P. 1997. The dissatisfaction potential of satisfied customers: The qualitative satisfaction model.

Working paper no. 111-131, Deutscher Universitätsverlag, Wiesbaden, DE.

Venkatesh, V., \& Davis, F.D. 2000. A theoretical extension of the technology acceptance model: Four longitudinal field stud- ies. Management Science, 46(2): 186-204. D0I: 10.1287/mnsc.46.2.186.11926

Wänke, M., \& Friese, M. 2005. The role of experience in consumer decisions: The case of brand loyalty. The Routines of Decision Making, 3(5): 289-309.

Wen, C., Prybutok, V. R., \& Xu, C. 2011. An integrated model for customer online repurchase intention. Journal of Computer Information Systems, 52(1): 14-23.

Yang, M.H., Lin, B., Chandlrees, N., \& Chao, H.Y. 2009. The effect of perceived ethical performance of shopping websites on consumer trust. Journal of Computer Information Systems, 50(1): 15-24. 